\title{
A questionnaire on ALT's usage of authentic English
}

\author{
NAKAMURA Youichi (Nagano-ken Shinonoi High School)
}

\section{Introduction}

Assistant language teachers teaching and/or team-teaching English in Japan, ALTs hereafter, are native speakers of English who struggle to communicate with their Japanese students in the front lines of the teaching/learning situation of their language. In their English classes, what kind of English do they speak? What kind of troubles do they face in communicating with their students? What do they do when they fail to communicate in English?

For all who are engaged in teaching English, especially for us non-native Japanese teachers of English, JTEs hereafter, it would be worth while hearing ALTs comments on the language they use in their classes, and listening to reports on their experiences when trying to communicate in English with their students. It would help us a lot by highlighting the problems our students face, and providing us with information which could then be taken into consideration for our English classes.

\section{Purpose}

The purpose of this paper is to discuss the points we must consider when teaching and testing communication ability, by exploring ALTs' comments on the usage of authentic English in their classes.

The term "authentic" in "authentic English," could be translated in many ways, such as "actual," "formal," "live," "natural," "real," "standard," "true" and so on. There could be a lot of discussions about what "authentic English" means. In this paper, however, we define "authentic English" as "the English ALTs.would speak back in their native town."

\section{Method}

To investigate our points, we gave a questionnaire to ALTs, on the usage of authentic English, asking about: 1) the frequency of usage; 2) the troubles students have with authentic English; 3) the strategies used when communication breaks down; 4) the differences of understanding in different grades; 5) their opinions about the usage of authentic English.

We mailed the questionnaire to 48 ALTs who are teaching and/or team-teaching at senior high schools in Nagano-ken, during the period between late June and early July, 1997. We received 20 completed questionnaires, the data from which is shown in Table 1. 
Sometimes. 7 (Male $-1+$ Female -6$)$

1) I try to use words in English I know they will understand.

2) Only when I teach Now Zealand colloquial English through role plays or other activities.

3) I speak a lot slower and I don't use slang. However I have been in Japan so long I can't remember how I used to speak to my friends and family.

4) Idiom \& slang are difficult to explain and understand. Speed is another problem. If you speak to quickly, oven with simple vocabulary, they $90 \%$ don't understand. They also possess limited vocabulary.

5) I want them to hoar real speech, but I usually have to repeat it slowly and clearly so they can understand.

6) I normally use a lot of slang when speaking to my family/friends, which students probably wouldn't understand, or particularly need to know. I also swear quite a lot, so I wouldn't want to learn them this!

Rarely. $\quad 9$ (Male - $4+$ Female - 5)

1) I speak much more slowly where, sticking to patterns and phrases students are familiar with, eliminating colloquialisms, slang, big words, unenuciated speech, etc.

2) I don't go to the classes often enough for them to get used to my "authentic English." Language classes should be everyday with a native speaker.

3) Because students don't understand authentic English. I speak more slowly and use less slang/colloquial language. Sometimes 1 reduce the number of words, or answer more fully, repeating the question a student asked. I use grammatically simple sentences.

4) It's too fast, use difficult words, slang accent. I don't think it's not beneficial.

5) Because my "authentic English" would be too colloquial for the students to understand and I use slang which is only used in NZ.

6) It is not possible for the students to understand. I doubt it would even be possible for the teachers to understand completely. This is not a criticism of teachers and students. It is just the facts when you are a non-native speaker.

7) Comprehension and slang are different lovels. Listening skills are low.

8) They don't know much English.

9) It would be inappropriate to do this in my high school. I'll do it on occasion with my higher level adults, mostly for interest sake.

Never. $\quad 3 \quad$ (Male $-2+$ Female -1$)$

1) They wouldn't understand! I have to speak very slowly, and use very simple words, phrases and sentences.

2) I speak much slowly, but I always speak proper/correct English. In that sense, I do speak "authentic" English, sometimes faster sometimes slower.

3) The primary reason is speed; but also my choice of words is very limited in Japan. The speed would rule our any kind of understanding. Just as, when Japanese people speak to me, I want them to speak more slowly, clearly and with a plausible choice of words. 
4-2 When you speak in an authentic way to the students in your English classes, what kind of problems do they experience with:

(1) Vocabulary (colloquially used words, "Japanese-English," etc.)

1) Colloquially used words.

2) When 1 introduce new words, I ask them what the word is in Japanese to check understanding. Colloquial words/phrases should be shown in context.

3) U. S. vs N. Z, England type English. It's very important to learn the differences. Many teachers think the majority of the world speaks U. S. style; in fact it's British!

4) I think this is the main problem. In Aust. we use a lot of slang. For ex. breakfast $\rightarrow$ brekky, afternoon $\rightarrow$ arro. This depends on the country your AET comes from.

5) Limited vocabulary so complex words or idiomatic phrases are nearly impossible to use. Everyday phrases for natives may not be understood. As well, Japanese English may convey an understandable meaning but it may not be the same meaning for the Japanese.

6) Range of vocabulary is often limited, vocabulary is "standard English" or sometimes old-fashioned English, so the students have problems with modern usage.

7) Of course, many words and particularly colloquial phrases, they've never come across in all their texts. I'm from the American South, for example, and I say 'y'all' as the plural of 'you.' Such regional dialect quirks can only really be learned through interaction, though, can't they, because there are too many to learn them all over.

8) They do not often understand colloquial words.

9) Because they have a very limited vocabulary, if you don't stick to words they know, they get lost. "Enjoy," "Play," "come to school," "Pretty," "very very," "my car/house/ ...," "delicious" are often misused.

10) They often know vocabulary from reading classes, not from oral classes, so I try to use words I know they are familiar with. Students don't know a lot of colloquial words.

11) Vocabulary is the biggest problem.

12) Yes, authentic English includes idioms, sayings, slang that of cause the students have never heard before. I face similar problems when listening to two Irish or Australian speak English. I can understand what they are saying but have some difficulties.

13) Low level of vocabulary and ability to respond also comprehension of listening is difficult. Must speak slowly and simply.

14) Limited vocabulary.

15) Students dwell on the words they do not know rather than the ones they do know.

(2) Grammar (inflection, word order, etc.)

1) Particles (a, an, the, otc ....).

2) Students find it hard placing pronouns and punctuation in sentences.

3) I don't think the grammar changes. 
4) Mixing tenses and verbs, like come and go. Japanese-English is ungrammatical $90 \%$ of the time. Mixing words, similar definitions but in a sentence wrong choice.

5) If speaking "authentically" the grammar is often too complicated for students to understand, they need more simple, straightforward, basic structures.

6) Yeah, mine's not partioularly good. Haven't found it to be much of a problem, except when l'm rambling. in which case it's too fast for them anyway.

7) Because English sentences can be ordered in so many different ways, and the students only learn 1 or 2, they find it difficult to understand if I don't speak in that way.

8) The/an/a is a problem, sometimes inversion of sentences into Japanese word order, problems spelling, esp. $L+R, B+V, d+b$, can't spell taking dictations.

9) $O K$.

10) The grammar is usually more complex or at least more varied; you don't have the concern of comprehension when you are speaking to friends or family, so you pay less attention to grammar.

11) Tends to get mixed up using Jap. style grammar.

12) Too complicated.

13) Students are confused by full use of proper grammar. Again, they allow the unfamiliarity of the sentence as a whole to dominate their reaction, rather than responding the key words.

(3) Pronunciation (vowels, consonants, adjustments in connected speech, accent, rhythm, stress, intonation, speed, etc.)

1) The katakana-ization of English words.

2) KATAKANA is a huge hindrance to English acquisition.

3) $R, L$ and $D$ seem to be the most difficult letters for my kids. Pronounce words like AND or DATE as ANDOH or DATEOH in a katakana way. Stress and intonation especially during question/answer type activities.

4) I think every country has a different accent. Even I have trouble listening to people from other countries.

5) The most obvious is l's and r's. Closely spelt words like different and difficult.

6) English vs American English is difficult for some students to understand. They find it difficult unless words are clearly pronounced and at a slower than normal speed.

7) Definitely speed and the slurring of prepositions (and any other short words that get in my way) when my talk really starts rolling. Pronunciation, too, when it differs from Japanese English, even if it's words they know, hamburger, print club.

8) I usually speak quite fast when using 'authentic' English; they cannot understand. My intonation also changes and they find it difficult to follow.

9) Can't understand unless each word is clearly pronounced.

10) Sometimes in class I write the words on the board the way they are actually pronounced. "How is it going?" $\rightarrow$ "How zit goin?"

11) I adopt an American pronunciation for some words (car, egg. bear ...). Speed is slower, and I pronounce words more clearly. 
12) The students have adjusted to my accent generally.

13) Speed is the main factor. With "authentic" English, we speak much faster.

14) $F, r$, th, are difficult also some connected speech. Speed is usually slow and flat rhythm.

15) British English (especially the southern British accent, ie: Queen's English) is probably easiest for Japanese to learn or understand as vowels are closest to Japanese $a, i, u, e, 0$; so I have few problems with pronunciation.

16) Katakana has ruined their English pronunciation. Roman letters are familiar enough in modern Japan.

(4) Social and/or cultural matters (differences between the two languages, etc.)

1) Most have no problem; they thrive on hearing about other cultures.

2) With my JTE we always explain differences in our cultures and between N. Z. and the U. S. A. Students enjoy hearing humorous stories about mistakes I have made speaking N. Z. English in U. S. A., like ordering Cola instead of Coke at Macdonalds and being asked to repeat myself!

3) No real problems.

4) Few problems; they seem to enjoy the differences.

5) Could easily be because I'm incredibly thick, but there've not been any issues that brought about complete communication breakdown in class, to my knowledge. Well, one time, I did try to talk about the US civil rights movement, and they just weren't particularly interested, which surprised me some.

6) Because of the Japanese education system / the way of teaching English, students generally don't look for a general meaning in a sentence, the 'gist.' Therefore they tend to respond with 'wakanai' if they cannot understand every single word.

7) There's no English for "gambate, yoroshiku, etc.," but students want to translate directly from Japanese. That's a problem.

8) This is a discussion point, rather than a problem.

9) Many of my students have never been on an air plane; things like this obviously will affect comprehension.

10) Difficult to get students to speak their minds and challenge themselves to think on their own without a conference about an answer. English tends to be more straight forward.

11) I often ask the JTL to translate a word for me into Japanese. I am disappointed whenever I get a "katakana" reply; I want to emphasize to the students that katakana is not English.

12) An unwillingness to try and understand; rather hoping that the JTE will provide a Japanese explanation. A shyness in class. (which, strangely, disappears when they talk to me outside the classroom!)

(5) Other

1) To address this issue, I made the enclosed list to help the students, especially with listening.

2) What do you mean authentic? I don't think any AET speaks to any Japanese as they would do with native friends. We want you to understand AETs who mumble, speak too quickly, and use slang are ignorant. 
3) I often use "textbook English" when I'm talking to my students so they have the chance to use the English they've learned. For example, l'd say "How aro you?" to my students, but "How's it going?" to my friends. So the English I use with my students is a little unnatural or formal.

4) They are very unused to listening to spoken English, so it's difficult for students to separate words in their heads as they listen; that's why I often speak one word; er. Read! instead of 'Would you read it, please?'

5) In all cases, students attempt to focus on the entirety of what l'm saying, rather than "zoning in" on the words that they do know and guessing the meaning from the context.

4-3 When you have trouble communicating with your students, what kind of strategies do you use to be understood, in terms of:

(1) Vocabulary (repetition, paraphrasing, mime, etc. )

1) paraphrasing.

2) I give examples, make analogies.

3) A lot of gestures, drawings and short stories in English about the misunderstood word which they then try to guess.

4) I usually repeat it once, then use really easy, basic words with actions.

5) Repetition is great. Dictionary. Speaking, mixing Japanese \& English to create comprehension.

6) Use of simpler vocabulary, trying to repeat similar vocabulary whenever possible in each lesson, explaining once, then paraphrasing.

7) Whatever's effective, depending on the word, right? If I can keep the student looking at me, and keep the other teacher from saying the word in Japanese, we can usually figure it out eventually.

8) I repeat things slowly or say it in a different way. I also use miming and facial expressions. I teach them colloquial vocabulary.

9) All of the above + drawing pictures, using examples, and explaining in Japanese as a last resort that somotimes necossary and not always ovil.

10) I use Japanese English If I can. I repeat the words, I paraphrase, I give a translation if I can. I gesture. I write the word down. Use the dictionary.

11) Mime, rephrase, describe the word, put word in context. og. humidity; This is in the summer, when the air is full of water, I feel very hot.

12) Also, pictures and examples of use of the word.

13) Ropotition, paraphrasing, use simpler words, use pictures on the blackboard, use body language, try different words.

14) Usually do choral repetition. 1st, smaller groups repeat, single out those who have serious problems to repeat a fow more times. Then pair work/practice on their own time circulating. Mime or draw images for them.

15) All of these and sometimes spelling.

16) Paraphrasing, mime, gestures. Writing it on the blackboard. Sometimes asking them to consult thoir dictionaries. 
17) I speak more slowly. Natural flow of language doesn't usually happen when I slow down too much. Paraphrasing and repetition work well.

18) Repetition, paraphrasing, more reliance on non-verbal communication.

(2) Grammar (paraphrasing, avoiding long sentences, etc.)

1) Always use short sentences (because that what I prefer when people speak to me in Japanese).

2) Using simple structures, speaking in "sections" allowing the students time to think in Japanese.

3) This comes up most in writing; trying to make sentences they aren't afraid of that still sound natural is a real challenge.

4) I tend to use grammar structure I think they'd understand, and to express things in the easiest way possible.

5) Give simple equivalents, acting things out, giving lots of examples.

6) I paraphrase. I use simple grammar structures. I break sentences into a series of points, ie. "Yesterday ... I went to Tokyo ..."

7) Shorten sentences, use easy vocab to illustrate a grammar point, simplify grammar.

8) Simplifying my English.

9) Short sentences, take things step by step.

10) Short sentences/mime and show an example.

11) I try to use things they are familiar with, short, slow sentences and repetition.

12) Simple sentence structure. Keeping my speech very concise.

13) I try to use simple constructions with minimal linking of clause.

(3) Pronunciation (speaking word by word, slowing speed, repetition, using Japanese-like pronunciation, etc.)

1) I show them what my mouth is doing.

2) A little repetition. Sentence game; I make students choose a word from about 25 word cards then in a group they make a sentence using that word then 1 student tells me the sentence and if it's wrong (grammar, pronunciation etc) they repeat after me. FUN GAMES!! The groups race against each other in a time limit to earn points for each sentence. Each student has to speak.

3) I try not to use Japanese pronunciation simply because I find my pronunciation of katakana is usually wrong.

4) Slow speed is top's. Simple words.

5) Explaining the American-English they often know, and then my British-English pronunciation. Speaking slowly and clearly, repeating each sentence.

6) All of these. I find if I gradually slow down the pace, it sort of illustrates the progression to spoken English from the word on the page. (backwards) Also trying to teach things like "gonna" and " $t$ 'do," so they recognize it.

7) I tend to slow down, and occasionally resort to Japanese-like pronunciation. However I don't think that speaking like 'katakana' actually helps students to learn English, so I try and avoid it.

8) I might write down the words, slow down. I never do that (Japanese-like pronunciation) if I can help it. 
9) I don't use katakana English over and I wish that katakana was forbiddon in the classrooms.

10) Slow speed, pronounce more clearly, American pronunciation, repetition, ... .

11) Slow down. Write out on the board. Repetition. I never use Japanese like pronunciation.

12) I never use Japanese pronunciation of English in class.

13) Slow down, sometimes use Japanese-like pronunciation but always explain the English pronunciation after doing so.

14) Use repetition only at beginning of lesson. Slow speed/any voice only, never imitate Japanese voice.

15) I try to avoid Japanese pronunciation unless the students is not able to understand after several slow repotitions.

16) Speaking slowly. Repetition. Never using Japanese-like pronunciation.

17) I slow down, but I don't ever go word-by-word. I repeat and tell the students to watch my mouth, and to speak clearly. I tell them to exaggerate English sounds. I NEVER use Japanese pronunciation!!!!

18) Slowly, cloarly.

(4) Social and/or cultural matters (avoiding the topics, etc.)

1) Explaining a different way, by using the chalk board, bringing in magazines, nowspaper, internet material.

2) I usually try to expose them to difficult topics using easy English, or a little Japanese if very complicated.

3) We compare high school life in our countries through role play.

4) I raroly avoid topics. Usually it produces the most interesting conversation.

5) Addressing the matter in both English and Japanese. Encouraging expression in a bilingual matter.

6) It's usually with teachers that I avoid topics. If a teacher asks a difficult question, that usually turns into a discussion in English at the front of the room, and the students don't get anything out of that.

7) I try and be sympathetic to students' social shyness, but at the same time I really want them to develop their creativity and independent expression of English, so I deliberately don't give them too much 'leeway.' I encourage them not to be shy and heartily praise any glimmer of creativity.

8) Try to explain simple differences or use lessons to explain them, ie, contrasty school life in the US, teaching how to explain Japanese customs like New Years, or foods, like mochi.

9) 1 st, give background, prepare students with ideas and vocabulary. Introduce cultural matters.

10) I chose topics which I think are interesting for students, but there are more complex (adult) issues which I don't think I should teach the students.

11) Use blackboard a lot. This is a big part of our jobs, we have to explain how things are in our country to compared to Japan. In reality, though, things aren't that different in my opinion.

12) Avoid social issues.

13) I don't try to avoid these things as they are often what makes studying language interesting. If the concept is complex 1 just have the JTE translate. The students seem interested.

14) The only thing preventing me from discussing certain topics is their complexity and the language/vocabulary barrier. Discussion is limitod, thus important issues are sometimes trivialized.

15) Explanation. 


\section{(5) Other}

1) It is important to create a frame of reference for them.

2) Understanding (sometimes) what they say in Japanese and telling them the English. Using the JTE to paraphrase in Japanese. Using gestures.

3) Sign language! Drawing pictures, speak Japanese, use the dictionary. Often I write the words down so they can read what I'm saying.

4) It's important to teach students basic tools to listen, ie a list of commands: 'Read,' 'Repeat after me.' 'Listen' etc, and a list of responses: 'I don't understand,' 'Once more, please.'

5) I ask them for translations of English words into Japanese and vice versa. Sometimes I drew pictures on the board or act out what I mean. To save time, I often ask the JTL present to provide a translation, but only for difficult points.

6) Often the important aim of my class is the activity, or the explanation. Therefore I also use Japanese or JTE. I do not believe Japanese should not be used in class.

4-4 What kind of differences do you feel when you speak in an authentic way, to the students of different grades, or to the students with different ability levels of English?

1) Of course the 2 nd \& 3rd year students understand me much better than the 1 st year students, because they're used to my speech patterns.

2) It's often a good way to lighten the mood of a class. It can be done at any level, but the students' initial understanding should be considered, or they will lose interest.

3) My 3rd gradors naturally understand my own colloquial English more easily rather than 1 st graders who are still trying to escape Junior High Text-book Americanisms!!!

4) When I speak in an authentic way I speak a lot faster. Between grades,... usually I speak slower to 1 st grade students. A little faster to 3rd grade (because I haven't taught them for one year) to my special 2nd grade class, I speak almost normal speed.

5) Often the less shy students understand more or will try to; which makes it easier to speak to them. Students with lower ability often find it difficult to understand/speak so grammar is very basic and many gestures are used. Students' ability is not always linked to their grade!

6) The younger students are far more reliant on katakana-type pronunciation. The older students have had more access to English songs/movies etc, and are more used to my voice, so they can understand my 'authentic English' easier.

7) I did a fow English camps with some high schools and I spoke to them like I would to my English speaking friends. I'm sure they weren't able to catch everything but it is good for them. Their level is high enough to understand the main idea.

8) Students who know even a little bit of "authentic English" give the impression that they are good English speakers and that they know something about the west. If "authentic English" could be integrated into the classes, it would make the students' English seem much more natural to a native speaker. 
9) Confidence and ability level go hand in hand. As I said, students of all levels should focus on what they know and not feel panic about what words they don't recognize. Conversation $=$ communication. It's not a grammar test.

10) Obviously, those students who are better have a better chance of understanding me.

4-5 What do you think about the usage of authentic English in your English classes? Is it effective in developing the students' ability to communicate? Please write any additional comments.

1) Authentic English, in my opinion, is the only way oral English should be taught. As soon as a teacher introduces nihon-go or pidgin/broken English into the lesson, the students suffer.

2) It is important, but it should be done with gradual exposure to new words and phrases, through familiarity.

3) It's very important students learn everyday English. My classes are special classes for this type of learning. I never use a set text. I teach them things like, ... how to order food from a menu ... how to arrange date, make a T.V. commercial in English. If you use fun activities and with your AET do an example of authentic English the students enjoy it.

4) I think it is interesting to learn some slang. Howover too much is an over load. Realistically most of the students will never use English and if they do, it will only be the sentences and words they heard or read often. I think I would be better to focus on the students ability to speak without being worried about making grammatical mistakes. Perfect grammar is wonderful. However it's not necessary to communicate.

5) Authentic way is useful for traveling but very confusing, most of the time. For those who have a high level, it is great to use to create a now challenge for them. Authentic English is good when it has a purpose. If not, for general teaching, keep it simple. Use it to a minimum unless it has relevance in a losson.

6) I don't think that too much emphasis should be placed on using authentic speed and vocabulary. Students must be encouraged to try, and for them to feel comfortable in doing so, it is necessary to simplify and slow down when speaking. Native speakers are often willing to speak more simply and slowly when communicating with foreigners, therefore the emphasis should be placed on communicating. If this happens, I believe, little by little the students will gain a more "authentic" ability in their English skills.

7) It's amazing how the folks who've spent any length of time in an English-speaking environment don't panic when you spoak normally. Things about authentic English is how very many different kinds there are. If my students learn real English conversation worthy of anyone in my town, but they can't adapt their communication \& understanding to any other English-speaking community, they're worse off than they were with just the text. I don't try to teach them my English except as an example of how one person differs from the "standard."

8) I think it's very important for the students to listen to authentic English, and use it. Katakana-type English does not help them communicate with English speaking people, as no ordinary English speaker would understand "basuketo" or "borupen." 
9) I don't feel that the way I speak is "unauthentic," exactly. I pick my words carefully and speak slowly, but that is necessary to be understood and much better than using only Japanese. It's important to work at their levels because the whole point is for them to see English as a tool they can use, and make it immediate and accessible to them. I try to avoid using Japanese English, though occasionally, l'll lapse into "very much" or "many many" or other unnatural phrases. I strongly avoid using ungrammatical, bad English, which I hear a lot of Japanese do ... "You. go. store." etc. At home, I tend to speak very quickly and colloquially, try to diversify my word choices, and often my family or friends don't even understand me.

10) First of all, students should be separated into language ability levels like they do in most countries. Language classes should be no greater than 15 for the advanced class. They should have class everyday and be expected to study outside the classrooms.

11) I think in term of vocals, we should teach more authentic English, for example "How's it going," "That's cool!" because it's used so often by native speakers. Using grammatically complicated English won't be beneficial for communication. I think that simplifying our English in terms of grammar is beneficial.

12) At school I don't speak in an authentic way. My accent is too strong, my words are too difficult. If I talk as I do with friends the students will freak and believe that they'll never get the hang of English. Authentic what? Authentic USA English? It has so many colloquial uses of words that I believe it is not important to learn. What are your goals in English education? Teaching authentic English = problems. You must decide which countries English you will use. What if I'm your AET. I can't teach American authentic English. I have tried to answer your questions but I fear my answers are not useful. I am unclear about "authentic." I don't speak to any non-native speaker of English in authentic English. I want to communicate and authentic English has too many barriers. Colloquial words change from country to country, region to region and through time. I think to teach colloquial "authentic" English is unnecessary. What are your goals as an English teacher? Don't reach so high as "authentic" English. The kids can hardly give directions let alone learn the subtle differences. Teachers ok because you have the foundation, but students? No, they have enough problems with standard English. Perhaps I have misunderstood "authentic" in this questionnaire. If so l'm sorry.

13) Please note that English has dialects/variations, so "authentic English" will be slightly different from country to country (and in different places within the same country). I adjust my English slightly when speaking to Americans, to make communication easier.

14) I think the students aren't ready for such high-level English, and that doesn't mean that our English instruction is failing them. You've got to learn to walk before you can run. The students have to try and communicate more, they know so much more English than they even realize. But they're shy. If we speak to them in too complete a way, they will only become more reserved in my opinion.

15) If students can understand more and carry on a better communication, they are getting better/understanding western culture. I believe it is good for students to be exposed to a foreigner and get a chance to let loose from the strict lectures of Japanese teaching. As for if it helps them communicate. It gives them opportunity to do so but it is only one hour a week which I feel is insufficient. Until oral communication is valued by the test giving authorities it will remain a challenge for many. 
16) I'm sorry but this is a difficult survey to fill out. There is very little natural English conversation at my schools, so I can't really answer detailed questions about it. The only students l've met that can converse somewhat naturally have done homestays abroad. These students are fow and far between. Personally, I think it's sad that some 3rd yoar H.S. students, after studying English 6 yoars can barely even introduce themselves in English. There are various reasons for this but this survey doesn't convey them. For example: The students have given up and don't study or try, lack of classroom discipline, etc. I hope some other AETs can help you out with your survey. Good Luck!

17) English is a language spoken around the world by millions of people. Each small group of English speakers uses the language slightly different manner. It would be pointless to teach students "my" particular form of English from "my" region of the world unless they were planning on using English only with that particular group of people. You must ask yourself why you are teaching English. Do your student wish to communicate only with one group of people? For example, using authentic English from the States when communicating with a business person from India might not be offective. I believe students need to be taught the basic, proper forms of the language first. It's only with my advanced adults that I stray into my "authentic" English. When I do this I also attempt to teach the British equivalents. "Authentic" English is interesting and a good motivator. The proper forms of English should however be well understood first and be understood as different from "authentic" English. Remember that one native speaker's form of "authentic" English may not be understood or appreciated by an English speaker from another part of the world.

18) I never speak in authentic English, even to my Japanese teaching colleagues. No, at my level schools, students need to grasp basic English sentence patterns, or basic vocab, before they can learn the intricacies of authentic English (idioms, colloquialism, etc.) However, I believe they are exposed to a certain degree of authentic English with a native English speakers. Certainly, they are exposed to natural English, oven if it isn't fully authentic!

19) Authentic English is vital. The alternative would be "unauthentic" English. Why would you teach an "unauthentic" version of a language? Students must learn more than technical aspects of English; they must accept the fact that their native language can not and must not exist for them when they speak in a second language. If they don't accept this reality, they'll never be able to communicate properly in any language other than their own.

20) I think authentic English (as you define it) should only be used at the top grades. Otherwise you discourage students because they cannot understand.

\section{Discussion}

5-1 The frequency of the usage of authentic English

Only one ALT answered that he always speaks in an authentic way. The majority, 12 out of 20 in number, claimed that they "rarely" or "never" use authentic English in their classes. That is, they speak to their Japanese students in some kind of adjusted, modified English in order to be understood. 
The reason the ALT who answered "always" gave is "Pidgin English does them no good." This opinion deserves further consideration. A similar comment on the usage of "pidgin" English is seen in 4-5-1). We have to consider, however, whether the language ALTs who answered negatively use is "pidgin" or not. Our definition of "authentic English" again is "the English they would speak back in their native town." Using this starting point, as the comment in 4-1-Never-2) shows, it can be said that the language ALTs who answered "rarely" or "never" use is "proper/correct" English, but is somewhat "different" in the speed of delivery and/or the vocabulary used, etc.

Here, it would be necessary for us to reconfirm that the English used by ALTs when teaching and/or team-teaching is "different" from their authentic English.

\section{5-2 The troubles students have with authentic English}

In this section, ALTs' comments on 5 categories will be discussed, from which differences between the English they use in their classes and an authentic English are revealed; how do they adjust and modify their authentic English? We would like to mention here, in advance, that the questions were given only to ALTs, and asked only for their comments ("what ALTs think") on such topics as "the troubles students would have with their authentic English."

(1) Vocabulary

The comment in 4-2-(1)-11) says, "Vocabulary is the biggest problem." Judging from all the other answers in this part, ALTs think that limited vocabulary is the main problem for their students.

The claims about limited vocabulary, such as in 4-2-(1)-5), 6), 9), 10), 15) should be taken carefully. "Everyday phrases for natives may not be understood," "Range of vocabulary is often limited," "old fashioned English," "misused," these can all cause communication breakdown.

Concerning the way of teaching/learning vocabulary, comments such as "know vocabulary from reading classes, not from oral classes" and "Students dwell on the words they do not know rather the ones they do know," must be examined carefully.

There remains a lot unsaid in the field of teaching and testing vocabulary. More analysis and research on "vocabulary" have to be done in future studies.

\section{(2) Grammar}

There are some opinions, such as "I don't think grammar changes" and "OK," in 4 2-(2)-3), 9). Some other ALTs think, however, "If speaking 'authentically' the grammar is often too complicated," as stated in the comments in 4-2-(2)-5), 7), 10), 12) 13). The comment in 4-2-(2)-5) says "they need more simple, straightforward, basic structure." Some point out the individual elements of English Grammar that our students would have troubles with. The points they gave are; "particles," "pronouns and punctuation," 
"mixing tenses and verbs," "word order," in 4-2-(2)-1), 2), 4), 8). Limited sentence patterns, troubles in spelling, interferences of Japanese are also referred to in 4-2-(2). 4), 7), 8), 11).

To make the points much clearer, assessment, that is diagnostic tests, should be carried out on our students' short-comings in the field of English grammar. Such assessment would be a starting point for the discussions seeking "the basic structure" needed in our English classes, which would bring communication ability into focus. And ALTs and JTEs could cooperate in the test, namely in "team -testing."

\section{(3) Pronunciation}

The comments in 4-2-(3)-6), 7), 8), 11), 13) 14) state, "Speed is the main factor." Difficulty of the individual sounds, such as " $r$ "." $l$ ", "d", " $f$ ", "th" are pointed out. Judging from the comments concerning "the way they are actually pronounced," provided in 4-2-(3)-6), 7), 9), 10), 11) 14), ALTs speak more "slowly than normal speed," "clearly," and with "flat rhythm." There are some who refer to the differences of American and British English, in 4-2-(3)-6), 11), 15). Some criticize Japanese "KATAKANA" in 4-2-(3)-1), 2), 3), 16).

As is suggested above in 5-2-(2) on grammar, diagnostic tests should be carried out also on our students' perception of the individual sounds, and adjustments in connected speech too. "What and how" to teach and test in the area of pronunciation should also be discussed. This is true for advanced levels, where capacity for communication in "real" situations is required; much more focus must be put on the adjustments in connected speech, that is on "the way they are actually pronounced."

About the differences between American and British English, there should be more discussions which lead to the theme, "Which kind of English should be brought into our English classes in Japan?"

The problems of KATAKANA, which would have a lot to do with the productive skills of our students, are also to be carefully considered. ALTs use the term "KATAKANA", but, in my opinion, the phenomenon might rather be connected with the "ROMAZI" teaching/learning that starts in the 4th year of Japanese public elementary schools. It is the first time Japanese elementary pupils learn the "roman alphabet" in public education and it is introduced through the system of expressing Japanese sounds, which end with a vowel, with the alphabet. The way of "ROMAZI" teaching/learning can be a great danger when starting to learn English in the 1st year at junior high. Students have a tendency to pronounce English words within the system of ROMAZI. Further discussions on this matter should be conducted in the future. 


\section{(4) Social and/or cultural matters}

The comments in 4-2-(4-1), 2), 3), 4), 5), 8) state, there would be "few problems" when teaching and discussing such matters in English classes, or rather, the cultural differences might, in fact, be a good resource in English classes.

About the general question of students' learning styles and/or attitude, the comments in 4-2-(4)-5), 6), 9), 10), 12) are especially worth listening to. They point out; “... about the US civil rights movement, and they just weren't particularly interested," "... they tend to respond with 'wakanai' if they cannot understand every single word," "Difficult to get students to speak their minds and challenge themselves to think on their own," "An unwillingness to try and understand; rather hoping that the JTE will provide a Japanese explanation. A shyness in class ... ."

Both JTEs and ALTs should inquire into the matter further. It would be a great help if ALTs were previously informed about the existing tendencies of students' attitude in class. The research on students' affective domain should be introduced and taken into our everyday classes. Efforts to make our students more active in class should be based on the results of the research concerned.

\section{(5) Other}

In this section, some interesting comments are seen. Among them, it should be noted here that an ALT kindly enclosed the list she had made on "Spoken American English," which suggests some good ways of teaching "actually spoken English" and some "everyday vocabulary." (See Appendix.)

\section{5-3 The strategies used when communication breaks down}

In the previous section, 5-2, we cited ALTs' comments and enumerated the points that should be discussed in the future. Here in this section, we quote comments on the strategies ALTs use in communication breakdown. These reports could provide useful tips to improve our instructing skills in English classes.

\section{(1) Vocabulary}

ALTs use repetition, paraphrasing, mime, "facial expressions" and "drawings" a lot. Using Japanese is thought as "a last resort." (See 4-3-(1-5), 10).) The comment in 43-(1)-7) should be taken carefully, especially for JTEs; "If I can ... keep the other teacher from saying the word in Japanese, we can usually figure it out eventually."

One thing we would like to note here, is the extent to which we may have "reliance on non-verbal communication." Our English classes are classes of "language" or "verbal communication." Into the question of "non-verbal communication" in our English classes, more investigation would be needed. 


\section{(2) Grammar}

ALTs use "short sentences," "simple structures," "speaking in 'sections'," "familiar sentences," and "minimal linking of clauses."

As suggested above in 5-2-(2), the diagnostic tests should come first, and then discussions to seek "the basic structure." - With this discussion, the basic structure would be graded, and presented in stages for the individual level of students' communication ability, not staying or remaining only in "short sentences" and "simple structures" levels.

(3) Pronunciation

ALTs speak "slowly" and "clearly," with "flat rhythm."

To brush up students' listening ability, however, not only sticking to the "present" level of communicability, there should be a lot of discussions about the pronunciation of the language ALTs speak in the classes, that is, the language our students are exposed to.

(4) Social and/or cultural matters

ALTs do try explaining certain matters, but they face "the language/vocabulary barrier." And they sometimes "avoid social issues," then "Discussion is limited, thus important issues are sometimes trivialized." There, again, is the comment in 4-3-(4). 6), that JTEs have to listen to carefully; "It's usually with teachers that I avoid topics. If a teacher asks a difficult question, that usually turns into a discussion in English at the front of the room, and the students don't get anything out of that."

Concerning the matter of Japanese students' attitude in the class, the comment in 4-3-(4)-7) makes the point; "I try and be sympathetic to students' social shyness, but at the same time I really want them to develop their creativity and independent expression of English."

(5) Other

Among some interesting comments in this part, two comments are to be cited here. The first is in 4-3-(5)-1); "It is important to create a frame of reference for them." And the second is in 4-3-(5)-4); "It's important to teach students basic tools to listen." These two comments appear to point out the important goals for team-taught lessons.

\subsection{The differences of understanding in different grades}

ALTs think, "Obviously, those who are better have a better chance of understanding me," "Confidence and ability level go hand in hand." So, as is seen in 4-4-4), "usually I speak slower to 1st grade students. A little faster to 3 rd grade (because I haven't taught them for one year), to my special 2nd grade class, I speak almost normal speed." One more interesting comment in 4.4-5) is cited here; "Often the less shy students 
understand more or will try to; which makes it easier to speak to them. ... Students' ability is not always linked to their grade!"

Intuitively, there would be some differences between the grades. To make the points clearer in detail, however, some assessment would be needed. The graded stages in teaching/learning communication ability in English, would be extracted from the results of the assessment.

\subsection{Their opinions about the usage of authentic English}

Here in this part, many absorbing comments, containing pros and cons on the usage of authentic English in our classes, are provided. Among them are; "It's important, but it should be done with gradual exposure to ...," "However too much is an over load," "Authentic English is good when it has a purpose. If not, for general teaching, keep it simple," "I don't think that too much emphasis should be placed on using authentic speed and vocabulary," "I think authentic English should only be used at the top grades," in 4-5-2), 4), 5), 6), 20). And concerning listening, we can read; "I think it's very important for the students to listen to authentic English," "I think in term of vocals, we should teach more authentic English," in 4-5-8), 11). Again, these comments could be a starting point for much needed discussion.

There, the comments regarding the "variety" of English language and "what authentic English is," are seen in 4-5-6), 7), 9), 12), 13), 17), 18), 19). Further, we can read the most important thing in 4-5-12), 17), concerning the English that has to be brought into our classes.

The contents of "the foundation" (4-5-12)) and "the basic, proper forms of the language" (4-5-17)) are the things that should be made clearer in future studies.

References to "Katakana-type English" in 4-5-8), "students should be separated into language ability levels" in 4-5-10), on "readiness of students" in 4-5-14), on the problems of "the test giving authorities" in 4-5-15), on "attitude and motivation" in 4 . 5-16) are also worth listening to, for JTEs to improve the environment of English education in Japan.

\section{Conclusion}

In our discussion here, we have tried to reveal some of the points we should consider when teaching and testing communication ability in English. ALTs' comments provided in this paper suggest that the English they use in the classroom is "different" from their "authentic English." In the differences between the usage of English, we could find some clues to start future discussions for our English classes.

There still remain many problems unsettled in this field, leaving much scope for the future research. 
Finally, I would like to thank the 20 ALTs who completed the questionnaire for their cooperation and time. I would also like to express my thanks to Miss Emma Yandell, an ALT from England, who read the draft of this paper and gave me helpful suggestions to make my English sound more "authentic."

Appendix The list of Spoken American English,

made by Ms Jennifer Huang, an ALT in Nagano-ken.

Spoken American English

\section{Grothe}

oHley (noment!

-How's it going? (Howrit goin'?)

-What's up?

-Whe's going on?

\begin{tabular}{|c|c|}
\hline Tertbook Enging & Spoken Engtish \\
\hline man I read may books.] & 2 lot of (I roed slot of books) \\
\hline ennge This milk tutes tronge.] & woind [This milk turtes weind] \\
\hline very [It's yery hot todny.] & 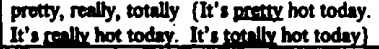 \\
\hline 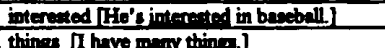 & into (He'cimis beochell) \\
\hline 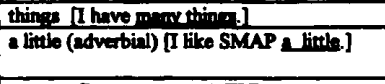 & 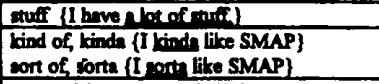 \\
\hline 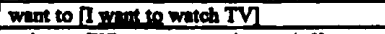 & werme (I ramen wrech TV) \\
\hline going to [Whe ere you ming to do?] & Sompe (What are you gonn do?) \\
\hline have to [I have to so home now] & $\begin{array}{l}\text { hafta (I breft go home now.) } \\
\text { gotts (I gotta go home now.) }\end{array}$ \\
\hline 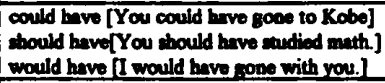 & 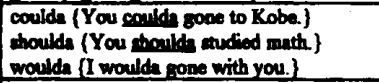 \\
\hline you [How wre you?] & ye (How ere n? (comecimes che or $j a)$ \\
\hline what are you [Whet are you doing?] & 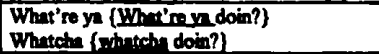 \\
\hline What do you [shen do mo were to do?] & 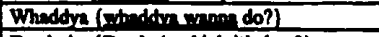 \\
\hline don't you Mon't you think h's late?l & 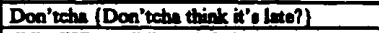 \\
\hline did you [Where fid you go?] & 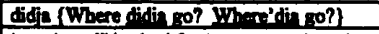 \\
\hline 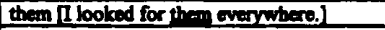 & 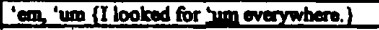 \\
\hline 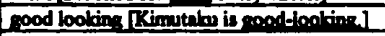 & 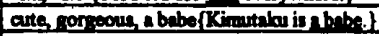 \\
\hline & \\
\hline underitand [Do you m & it $1 D_{0}$ \\
\hline 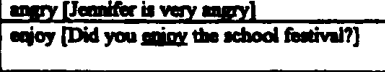 & 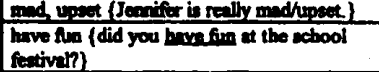 \\
\hline
\end{tabular}

\section{Other 8000 words:}

cool: kaldkoi. when comerthing is interesting good-looking, fien or good in rome way. "She seems like a cool person." "That's a cool car."

"Weme go to Miasu?" "That's cool."

messed vin: mechakuchs. When romething's dirty, wrong or bad "My room is all meased up." "I messed up on my teot"

never mind forcet it: nandemonai. maritya. "What did you say?" "Never mind."

Bewny! : usol When you are aurpriced and don't believe the person. "I'm going to be in the Otympics!" "No way!"

gros: kimochi warui. When comething is bad, unpleasunt.

"Enting natto with ice creem is gross!" "Seven' whs a gross movie."

gtinks, netes: kusi. when something bad happens ('stinks' only) or when something smells bad (both)

"You bat the basoball game? That atinks." "Natto really reeks." "His shoes stink."

hang out: epend time doing nothing specill. "Let's hang out in Musumoto." "We just hung out at my house on Saturday."

scared to be afrid. When I was little, I was scared of the dark

Ross: Hoy Joey, wher's up?

Joey: Nothing much. I'm studying math. I got $17 \%$ (percent) on my last test.

Ros: No wayl That etinks. You ahoulds studied before the test. But hoyl You warna g out tonight?

Joey. Nope, Ive gotte study. Where're ye goin'?

Ross: Well, I wana go soe that now movie, "Sleepers". Don'tcha wanna go?

Joey: No, Im not really into movies. And I just don't get my muth homework. But you wana play basketball tomorrow?

Dous: Sure, what time?

Joey. How about two thirty?

Ross: Ok, I'll meetchn at the peri 


\section{References}

Bachman, L. F. 1990. Fundamental considerations in language testing. Oxford, UK.: OUP.

Bachman, L. F. \& Palmer, A. S. 1996. Language testing in practice. Oxford, UK.: OUP.

Brinton, D. M. 1997. 'Teaching pronunciation in the EFL context: Some considerations.'『学習評価研究』No. 30 夏号. 東京 : みくに出版.

Brinton, D. M. 1998. 'Wahchadooin? Teaching reduced speech!'『学習評価研 究』No. 32 春号. 東京：みくに出版.

Brown, H. D. 1987. Principles of language learning and teaching. Second edition. Englewood Cliffs, NJ: Prentice-Hall Regents.

Campbell, R. N. 1994. 'Things your students ought to know.' 『学習評価研究』 No. 20 冬号. 東京：みくに出版.

Campbell, R. N. 1995. 'Things your students ought to know: Part two.'『学習評 価研究』No. 21 春号. 東京：みくに出版.

Campbell, R. N. 1996. 'Teaching grammar in EFL courses.' 『学習評価研究』No. 25 春号. 東京: みくに出版.

Campbell, R. N. 1996. 'Listening.' 『学習評価研究』No. 28 冬号. 東京: みく に出版.

Campbell, R. N. 1997. 'Developing listening proficiency.'『学習評価研究』 No. 29 春号. 東京：みくに出版.

Celce-Murcia, M., Brinton, D. M. \& Goodwin, J. M. 1996. Teaching pronunciation: A reference for teachers of English to speakers of other languages. Cambridge, UK.:CUP.

Engel, R. 1994. Cultural issues faced by the American-educated teacher in a Japanese high school: Suggestions for expanded training. Nashville, TN: Educators Press.

Rost, M. 1990. Listening in language learning. New York: Longman. 